Hubungan Antara Kontrol Diri dan Komitmen Kerja Dengan Perilaku Cyber-loafing

Pada Pegawai Negeri Sipil (PNS) Dinas X Provinsi Jawa Tengah

Proyeksi, Vol. 16 (1) 2021, 100-108

\title{
HUBUNGAN ANTARA KONTROL DIRI DAN KOMITMEN KERJA DENGAN PERILAKU CYBER- LOAFING PADA PEGAWAI NEGERI SIPIL (PNS) DINAS X PROVINSI JAWA TENGAH
}

\author{
Dewi Khikmatul Hidayah dan Agustin Handayani \\ Fakultas Psikologi,Universitas Islam Sultan Agung \\ E-mail: dewikhikmatul@yahoo.com, agustinhandayani75@gmail.com
}

\begin{abstract}
Abstrak
Penelitian ini bertujuan untuk mengetahui hubungan antara kontrol diri dan komitmen kerja dengan perilaku cyber-loafing pada pegawai negeri sipil Dinas $X$ Provinsi Jawa Tengah. Populasi dalam penelitian ini yaitu pegawai negeri Dinas $X$ provinsi Jawa Tengah dengan sampel berjumlah 150 pegawai. Teknik pengambilan sampel menggunakan simple random sampling. Alat ukur dalam penelitian ini terdiri dari tiga skala. Skala kontrol diri terdiri dari 19 aitem dengan koefisien reliabiltas 0,764, skala komitmen kerja terdiri dari 20 aitem dengan koefisien reliabilitas 0,789 dan skala perilaku cyber-loafing terdiri dari 14 aitem dengan koefisien reliabilitas 0,741 . Teknik analisis data menggunakan korelasi product moment dan pearson. Hasil hipotesis yang dilakukan menunjukkan bahwa skor $\mathrm{R}=0,214 \mathrm{~F}$ sebesar $=12,792$ dengan taraf signifikasi $p=0,000(p<0,05)$ yang artinya ada hubungan antara kontrol diri dan komitmen kerja dengan perilaku cyber-loafing. Hipotesis kedua memperoleh hasil $r_{x 1 y}$ sebesar $=-0,461$ dan signifikasi $=0,000(p<0,05)$. Dengan hasil tersebut dapat diketahui bahwa ada hubungan negatif antara kontrol diri dengan perilaku cyber-loafing. Hipotesis ketiga memperoleh hasil $r_{x 1 y}=-0,327$ dengan signifikasi sebesar $=-0,001(p<0,05)$. Hasil tersebut membuktikan bahwa ada hubungan negatif antara kontrol diri dengan perilaku cyber-loafing.
\end{abstract}

Kata kunci : cyber-loafing, kontrol diri, komitmen kerja

\section{THE CORRELATION BETWEEN SELF-CONTROL AND WORK COMMITMENT WITH CYBER-LOAFING BEHAVIOR AMONG CIVIL SERVICE EMPLOYEES AT GOVERNMENT OFFICE X CENTRAL JAVA PROVINCE}

\begin{abstract}
This study aims to determine the correlations between self-control and work commitment with cyber-loafing behavior among civil servant at government office X Central Java Province. The population in this study are civil servants at government office $X$ in Central Java Province with a sample of 150 employees. The sample technique uses simple random sampling. The measuring instrument in this study consists of three scales. The self-control scale consists of 19 items with a reliability coefficient of 0,764, the work commitment scale consists of 20 items with a reliability coefficient of 0,789 and the cyber-loafing scale consists of 14 items with a reliability coefficient of 0,741 . The data analysis technique used the Pearson's product moment. The result of the data analysis showed that the score $R=0,214 \quad F=12,792$ with a significance $p=0,000 \quad(p<0,05)$ which means that there is a correlation between self-control and work commitment to cyber-loafing behavior. The second hypothesis obtained the result of $r \times 1 y=-0,461$ and significance $p=0,000(p<0,005)$ with the results it can be seen that there is a negative correlation between self-control and cyber-loafing behavior. The third hypothesis obtained the results of $r \times 1 y=-0,327$ with a significance $p=0,001 \quad(p<0,005)$. These results prove that there is a negative correlation between self-control and cyber-loafing behavior.
\end{abstract}

Keywords: self-control, work commitment, cyber-loafing 


\section{Pendahuluan}

Hasil survei mengenai penetrasi pengguna internet di Indonesia yang dilakukan oleh Asosiasi Penyelenggara Jasa Internet Indonesia (APJII) pada tahun 2017 mengatakan bahwa pengguna internet di Indonesia sebanyak 143,26 juta jiwa dari total populasi seluruh penduduk Negara Indonesia 262 juta jiwa, dengan kata lain sekitar 54,68\% penduduk Indonesia menggunakan internet untuk kebutuhan sehari-hari. Pulau Jawa merupakan pengguna internet terbanyak dibandingkan dengan pulau lainnya yaitu sekitar 58,08\% dari seluruh pulau di Indonesia (APJII, 2017).

Berdasarkan penelitian yang dilakukan oleh peneliti masyarakat yang banyak menggunakan internet merupakan masyarakat yang memiliki tingkat pendidikan terakhir S2 atau S3 dengan presentase sekitar 88,24\% (APJII, 2017). Masyarakat dengan tingkat pendidikan tersebut merupakan masyarakat yang bekerja setiap harinya.Rata-rata masyarakat Indonesia menghabiskan waktu setiap hari dalam jangka waktu 1-3 jam perhari untuk menggunakan internet. Berikut tiga layanan yang digunakan oleh pengguna internet diantaranya chatting, social media dan game.

Namun di sisi lain berdasarkan fakta yang ada di lapangan, dengan difasilitasinya berbagai macam sarana prasarana dan tingginya pengguna internet di Indonesia khususnya pulau Jawa memiliki dampak negatif bagi penggunanya jika terlalu sering menggunakannya di saat waktu yang tidak tepat. Pegawai akan melalaikan kewajibannya untuk melaksanakan tugas tersebut. Para pegawai akan memanfaatkan sarana dan prasarana yang disediakan oleh pemerintah untuk kepentingan pribadi seperti chatting, game online, browsing instagram, Facebook, Youtube dan lain sebagainya. Perilaku tersebut dinamakan dengan istilah cyber-loafing.

Cyber-loafing merupakan sebuah perilaku menyimpang pegawai dimana para pegawai menggunakan status pegawainya untuk mengakses internet dengan tujuan yang tidak ada kaitannya dengan pekerjaan (Lim, 2002). Contoh perilaku cyber-loafing diantaranya seperti menggunakan komputer untuk game, memakai telepon kantor untuk kepentingan pribadi pegawai, menggunakan handphone pada saat meetinguntuk mengirim pesan, mengendarai mobil dinas untuk kepentingan keluarga dan lain sebagainya. Dengan adanya perilaku menyimpang tersebut akan merugikan instansi pemerintah. Kerugian dapat dalam bentuk waktu mapun biaya yang dikeluarkan pemerintah.

Cyber-loafing atau juga disebut cyberslacking adalah suatu perilaku yang dilakukan oleh para pegawai yang menggunakan internet dengan jenis komputer pada saat jam kerja dengan tujuan utnuk aktivitas non-destruktif, pegawai menganggap perilaku tersebut tidak berhubungan dengan pekerjaan diantaranya seperti menggunakan akses internet untuk hiburan, belanja online, chatting, internet messaging, memposting ke newsgroups dan mengunduh berbagai lagu serta film (Blanchard \& Henle, 2008).

Kontrol diri merupakan salah satu fungsi pusat yang berada dalam diri masing-masing individu yang diduga menimbulkan perilaku cyber-loafing. Menurut (Baumeister, 2002) kontrol diri seseorang mengacu pada sebuah kapasitas untuk mengubah atau mengarahkan respon seseorang terhadap suatu hal, termasuk pikiran, perasaan, emosi, dan tindakan secara sadar, terutama mengendalikan impuls dan melawan godaan yang bertentangan dengan diri seseorang. Sedangkan menurut Averill (Ghufron \& Risnawati, 2010) kontrol diri adalah kemampuan individu untuk memodifikasi perilaku, kemampuan individu dalam mengelola informasi yang diinginkan dan yang tidak diinginkan, dan kemampuan individu untuk memilih salah satu tindakan berdasarkan sesuatu yang diyakini. Aspek Averill dalam (Ghufron \& Risnawati, 2010) menyimpulkan mengenai kontrol diri diantaranya yaitu terdapat kontrol perilaku (behavioral control), kontrol kognitif (cognitive control) dan kontrol pengambilan keputusan (decision control). 
Faktor lain yang menyebabkan individu melakukan perilaku cyber-loafing adalah komitmen kerja. Komitmen kerja merupakan suatu kondisi yang dirasakan oleh para pegawai yang dapat menimbulkan sikap positif yang kuat terhadap organisasi kerja yang dimilikinya. Menurut(Porter \& Steers, 2013) komitmen kerja yaitu suatu bentuk komitmen kerja yang muncul bukan hanya bersifat loyalitas yang pasif saja, melainkan juga dapat melibatkan hubungan yang aktif dengan organisasi di tempat kerja yang memiliki tujuan memberikan segala usaha demi mencapai keberhasilan organisasi kerja yang bersangkutan. Komitmen kerja adalah derajat dimana pegawai percaya sepenuhnya terhadap perusahaan, menerima tujuan-tujuan perusahaan serta tetap tinggal dan tidak akan meninggalkan perusahaan(Mathis \& Jackson, 2008). Meyer \& Allen (1990) dalam (Fajrianthi, 2012) menjelaskan bahwa komitmen kerja dapat diartikan sebagai sejauh mana karyawan mengalami rasa kesatuan dengan organisasi mereka. lebih lanjut lagi. Aspek komitmen kerja menurut Meyer \& Allen dalam (Fajrianthi, 2012) dibagi menjadi tiga diantaranya yaitu komitmen afektif (affective commitment), komitmen kontinyu (continuance commitmen) dan komitmen normatif (normative commitment).

Penelitian yang dilakukan di Dinas $X$ Provinsi Jawa Tengah yang memiliki pegawai yang mayoritas berstatus Pegawai Negeri Sipil. Pegawai Dinas $X$ memiliki kewajiban penuh dalam menjalankan visi dan misinya. Kewajiban yang harus dilakukan adalah menggunakan jam kerja dengan sebaik mungkin. Pegawai Dinas $X$ memiliki pekerjaan yang menggunakan komputer. Hal ini memberikan peluang untuk menimbulkan intensi cyber-loafing. Salah satu cara untuk menggunakan jam kerja sebaik mungkin adalah menghindari cyber-loafing. Oleh karena itu dibutuhkan kontrol diri yang tinggi untuk mencegah timbulnya intensi cyber-loafing pada karyawan (Ozler \& Polat, 2012).

Penelitian ini bertujuan untuk mengetahui hubungan antara kontrol diri dan komitmen kerja dengan intensi cyber-loafing. Oleh karena itu, hipotesis yang diajukan pada penelitian ini adalah ada hubungan antara kontrol diri dan komitmen kerja dengan perilaku cyber-loafing pada pegawai negeri sipil Dinas X Provinsi Jawa Tengah. Ada hubungan yang negatif antara kontrol diri dengan perilaku cyber-loafing pada pegawai negeri sipil Dinas X Provinsi Jawa Tengah. Semakin tinggi kontrol diri yang diterapkan oleh pegawai negeri maka semakin rendah perilaku cyber-loafing. Ada hubungan yang negatif antara komitmen kerja dengan perilaku cyber-loafing pada pegawai negeri sipil Dinas $X$ Provinsi Jawa Tengah. Semakin tinggi komitmen kerja yang diterapkan oleh pegawai negeri maka semakin rendah pula perilaku cyber-loafing.

\section{Metode Penelitian}

\section{Rancangan Penelitian}

Penelitian ini menggunakan desain penelitian kuantitatif korelasional, dimana penelitian ini mempelajari hubungan dua variabel atau lebih, yakni sejauh mana variasi dalam satu variabel berhubungan dengan variabel lain. Alasan peneliti menggunakan penelitian korelasional adalah penelitian ini bertujuan untuk melihat hubungan antara dua variabel, yaitu variabel kontrol diri, komitmen kerja dan perilaku cyber-loafing.

\section{Subjek Penelitian}

Penelitian ini menyelidiki tentang hubungan antara kontrol diri dan komitmen kerja dengan perilaku cyber-loafing pada pegawai negeri. Karakteristik subjek penelitian yaitu laki-laki atau perempuan, pegawai negeri sipil dan bekerja menggunkan handphone atau komputer. Populasi dalam penelitian ini berjumlah 150 pegawai negeri Dinas $X$ Provinsi Jawa Tengah. Sampel merupakan 
sebagian atau wakil populasi yang diteliti. Jumlah sampel dalam penelitian ini sebanyak 97 pegawai negeri yang terdiri dari 6 bidang.

Tabel 1. Data PNS yang menjadi Subjek Penelitian

\begin{tabular}{clc}
\hline No & \multicolumn{1}{c}{ Bidang } & Jumlah \\
\hline 1 & Bidang Sekretariat & 35 \\
2 & Bidang Pembinaan Diksus & 11 \\
3 & Bidang Pembinaan SMA & 6 \\
4 & Bidang Pembinaan SMK & 17 \\
5 & Bidang Pembinaan Kebudayan & 11 \\
6 & Bidang Ketenagaan Pendidikan dan & 17 \\
& Kebudayaan & $\mathbf{9 7}$ \\
Total & & \\
\hline
\end{tabular}

\section{Variabel dan Instrumen Penelitian}

Skala cyber-loafing diambil dari(Blanchard \& Henle, 2008) dua aspek yang terdiri dari minor cyber-loafing dan serious cyber-loafing. Aitem yang tersedia berjumlah 20 aitem dengan 10 aitem favorable dan 10 aitem unfavorable. Skala cyber-loafing adalah sebuah skala model likert dengan format 4 poin yaitu SS (Sangat Sering), S (Sering), JR (Jarang), TP (Tidak Pernah). Dalam sklaa tersebut terdapat dua macam pernyatan diantaranya pernyataan yang mendukung (favorable) dan pernyataan yang tidak mendukung (unfavorable). Untuk penilaian jawaban yang tergolong favorable terdiri dari SS (Sangat Sering) yang bernilai 4, S (Sering) bernilai 3, JR (Jarang) bernilai 2 dan TP (Tidak Pernah) bernilai 1. Pilihan respon untuk aitem unfavorable yaitu SS (Sangat Sering) yang bernilai $1, S$ (Sering) bernilai 2, JR (Jarang) bernilai 3 dan TP (Tidak Pernah) bernilai 4. Pilihan respon untuk aitem unfavorable yaitu SS (Sangat Sering) yang bernilai 1, S (Sering) bernilai 2, JR (Jarang) bernilai 3 dan TP (Tidak Pernah) bernilai 4.

Skala kontrol diri dibuat berdasarkan pada tiga aspek Averill dalam (Ghufron \& Risnawati, 2010) yang terdiri dari aspek behavior control (kontrol perilaku), cognitive control (kontrol kognitif) dan decision control (kontrol pengambilan keputusan). Aitem yang tersedia berjumlah 30 aitem dengan 15 aitem favorable dan 15 aitem unfavorable. Skala kontrol diri merupakan sebuah skala likert yang menggunakan format 4 poin yaitu SS (Sangat Sesuai), S (Sesuai), TS (Tidak Sesuai), STS (Sangat Tidak Sesuai). Dalam skala tersebut terdapat dua macam pernyatan diantaranya pernyataan yang mendukung (favorable) dan pernyataan yang tidak mendukung (unfavorable). Untuk favorable yaitu SS (Sangat Sesuai) yang bernilai 4, S (Sesuai) yang bernilai 3, TS (Tidak Sesuai) yang bernilai 2 dan STS (Sangat Tidak Sesuai) bernilai 1. Pilihan respon untuk aitem unfavorable yaitu SS (Sangat Sesuai) yang bernilai $1, \mathrm{~S}$ (Sesuai) yang bernilai 2, TS (Tidak Sesuai) yang bernilai 3 dan STS (Sangat Tidak Sesuai) bernilai 4.

Skala komitmen kerja dibuat berdasarkan pada tiga aspek Meyers \& Allen dalam (Fajrianthi, 2012) yang terdiri dari aspek affective commitment (komitmen afektif), continue commitment (komitmen kontinyu) dan normative commitment (komitmen normatif). Aitem yang tersedia berjumlah 30 aitem dengan 15 aitem favorable dan 15 aitem unfavorable. . Skala komitmen kerja merupakan sebuah skala likert yang menggunakan format 4 poin yaitu SS (Sangat Sesuai), S (Sesuai), TS (Tidak Sesuai), STS (Sangat Tidak Sesuai). Dalam skala tersebut terdapat dua macam pernyatan diantaranya pernyataan yang mendukung (favorable) dan pernyataan yang tidak mendukung (unfavorable). Untuk favorable yaitu SS (Sangat Sesuai) yang bernilai 4, S (Sesuai) yang bernilai 3, TS 
(Tidak Sesuai) yang bernilai 2 dan STS (Sangat Tidak Sesuai) bernilai 1. Pilihan respon untuk aitem unfavorable yaitu SS (Sangat Sesuai) yang bernilai 1, S (Sesuai) yang bernilai 2, TS (Tidak Sesuai) yang bernilai 3 dan STS (Sangat Tidak Sesuai) bernilai 4.

Berikut hasil tryout skala kontrol diri, komitmen kerja dan perilaku cyber-loafing yang telah dilakukan oleh 53 subjek pegawai negeri sipil (PNS) mendapatkan hasil sebagai berikut:

Tabel 2. Indeks Validitas dan Reliabilitas Alat Ukur Penelitian

\begin{tabular}{lcccc}
\hline Alat Ukur & $\begin{array}{c}\text { Jumlah Aitem } \\
\text { Diajukan }\end{array}$ & $\begin{array}{c}\text { Jumlah Aitem } \\
\text { Valid }\end{array}$ & Indeks Validitas & $\begin{array}{c}\text { Indeks } \\
\text { Reliabilitas }\end{array}$ \\
\hline $\begin{array}{l}\text { Perilaku } \\
\text { loafing }\end{array}$ & 20 & 14 & $0,257-0,561$ & 0,741 \\
Kontrol Diri & 30 & 19 & $0,270-0,571$ & 0,764 \\
Komitmen Kerja & 30 & 20 & $0,270-0,532$ & 0,789 \\
\hline
\end{tabular}

Berdasarkan Tabel 2 menunjukkan indeks validitas diperoleh hasil dari 20 item skala perilaku cyberloafing, ada 14 item yang valid. Hasil pengujian koefisien validitas item berkisar antara 0,257 sampai dengan 0,561. Sedangkan hasil dari 30 item skala kontrol diri ada 19 item yang valid. Hasil pengujian koefisien validitas item berkisar antara 0,270 sampai 0,571. Hasil dari 30 aitem skala komitmen kerja ada 20 aitem yang valid. Hasil pengujian koefisien validitas aitem berkisar antara 0,270 sampai dengan 0,532. Ketiga instrumen yang dipakai dalam tryout penelitian ini reliabel karena reliabilitas pada setiap instrumen $>0,60$ (Cronbach Alpha). Hal ini membuktikan bahwa kedua instrumen yang dipakai dalam penelitian ini memiliki tingkat validitas dan reliabilitas yang memadai.

\section{Teknik Pengambilan Sampel}

Terdapat beberapa jenis teknik pengambilan sampel, namun dalam penelitian ini peneliti menggunakan teknik Simple Random Sampling. Simple Random Sampling didefinisikan sebagai metode pengambilan sampel yang dilakukan secara random atau acak. Dengan cara pengambilan sampel seperti ini seluruh anggota populasi diasumsikan memiliki kesempatan yang sama untuk terpilih menjadi sampel penelitian.

\section{Teknik Analisis Data}

Analisis data adalah cara yang digunakan dalam mengolah data yang diperoleh sehingga dapat ditarik sebuah kesimpulan (Azwar, 2012). Metode yang digunakan pada penelitian ini adalah metode penelitian kuantitatif dengan menggunakan statistik. Penelitian ini menggunakan teknik analisis regresi linier berganda dan korelasi pearson yaitu suatu metode statistik umum yang digunakan untuk meneliti hubungan antara sebuah variabel tergantung dengan beberapa variabel bebas. Pada penelitian ini perhitungan data dihitung dengan menggunakan bantuan program SPSS (Statistical Product and Service Solution) for Windows Release Versi 20.0.

\section{Hasil}

Data penelitian yang terkumpul kemudian dilakukan analisis. Sebelum melakukan uji korelasi, terlebih dahulau dilakukan uji asumsi yang terdiri dari uji normalitas, uji linieritas dan uji multikolininieritas. 


\section{Uji Normalitas}

Uji normalitas mempunyai tujuan untuk mengetahui normal atau tidak normal persebaran data disetiap variabel penlitian. Uji Normalitas peneliti yang akan digunakan adalah One Sample Kolmogorov Smirnov Z (KS-Z) dengan dibantu program SPSS versi 20.0. Kriteria yang dipakai untuk menentukan penyebaran data normal ataupun tidak normal ialah apabila $p>0,05$ bisa dikatakan data tersebut normal, namun jika $p<0,05$ yang berarti data tersebut tidak normal.

Tabel 3. Hasil Uji Normalitas

\begin{tabular}{lcccrcr}
\hline \multicolumn{1}{c}{ Variabel } & Mean & Std Deviasi & KS-Z & Sig & $\boldsymbol{P}$ & Ket. \\
\hline $\begin{array}{l}\text { Perilaku Cyber- } \\
\text { loafing }\end{array}$ & 26,85 & 6,987 & 1,235 & 0,095 & $>0,05$ & Normal \\
$\begin{array}{l}\text { Kontrol Diri } \\
\text { Komitmen Kerja }\end{array}$ & 62,69 & 4,829 & 0,812 & 0,525 & $>0,05$ & Normal \\
& 63,77 & 7,294 & 1,002 & 0,268 & $>0,05$ & Normal \\
\hline
\end{tabular}

Berdasarkan hasil uji normalitas dengan sebaran data perilaku cyber-loafing memperoleh nilai KS-Z sebesar 1,235 dengan taraf signifikasi 0,095 $(p>0,05)$ yang menunjukan bahwa perilaku cyber-loafing mempunyai distribusi data yang normal. Hasil uji normalitas pada sebaran data kontrol diri dengan nilai KS-Z di peroleh sebesar 0,812 mempunyai taraf signifikasi 0,525 ( $p>0,05)$ melihatkan bahwa kontrol diri mempunyai distribusi data yang normal. Hasil uji normalitas pada sebaran data komitmen kerja dengan nilain KS-Z 1,002 dengan taraf signifikasi 0,268 ( $p>0,05)$ dengan menunjukan nilai tersebut dapat di sebutkan maka komitmen kerja mengalami distribusi data yang normal.

\section{Uji Linieritas}

Hasil uji linieritas yang diperoleh antara variabel Perilaku Cyber-loafing dengan kontrol diri yaitu sebesar 25,699 dengan taraf signifikasi $p=0,000(p<0,05)$. Hasil tersebut melihatkan bahwa adanya hubungan linier atau membentuk garis lurus antara Perilaku Cyber-loafing dengan kontrol diri. Sedangkan hasil yang didapatkan pada saat pengujian linieritas variabel intensitas Perilaku Cyber-loafing dengan Komitmen Kerja memperoleh hasil sebesar 11,400 dengan taraf signifikasi $p=0,001(p<0,05)$. Hasil tersebut melihatkan bahwa adanya hubungan linier atau membentuk garis lurus antara Perilaku Cyber-loafing dengan komitmen kerja.

\section{Uji Multikolinieritas}

Hasil yang diperoleh dari uji multikolinieritas menunjukan bahwa VIF 1,760 (VIF < 10) dan tolerance 0,568 $(>0,1)$. Sehingga hasil tersebut dapat diketahui bahwa peneliti tidak terjadi multikolinieritas pada variabel bebas model regresi sehingga bisa dilanjutkan untuk melihat hubungan antar variabel.

\section{Uji Hipotesis}

Uji korelasi pada penelitian ini menggunakan analisis regresi sederhana berganda. Uji Korelasi pertama ini mempunyai tujuan untuk menguji apakah ada hubungan antara kontrol diri dan komitmen kerja dengan perilaku cyber-loafing pada pegawai negeri dan dapat diketahui bahwa hasil uji korelasi yang di dapatkan pada skor $\mathrm{R}=0,214 \mathrm{~F}$ sebesar $=12,792$ dengan taraf signifikasi $p=0,000$ $(p<0,05)$.

105 
Uji korelasi pada hipotsis kedua ini menggunakan uji korelasi pearson. Uji korelasi yang kedua ini pada peneliti dapat dilihat ada atau tidaknya hubungan antara variabel perilaku cyberloafing dengan kontrol diri. Berdasarkan hasil dari variabel perilaku cyber-loafing dengan kontrol diri diperoleh hasil $r_{x 1 y}=-0,461$ dengan signifikasi sebesar $0,000(p<0,05)$.

Uji korelasi pada hipotsis ketiga ini menggunakan uji korelasi pearson. Uji korelasi yang ketiga ini pada peneliti dapat dilihat ada atau tidaknya hubungan antara variabel perilaku cyber-loafing dengan komitmen kerja. Berdasarkan hasil dari perilaku cyber-loafing dengan komitmen kerja diperoleh hasil $r_{x 1 y}=-0,327$ dengan nilai signifikasi sebesar $0,001(p<0,05)$.

\section{Pembahasan}

Penelitian ini dilakukan dengan tujuan untuk memahami apakah ada hubungan antara kontrol diri dan komitmen kerja dengan perilaku cyber-loafing pada pegawai negeri dinas $\mathrm{x}$ Provinsi Jawa Tengah. Berdasarkan dari hasil penelitian yang telah dilaksanakan, penelitian ini mempunyai tiga hipotesis. Hipotesis pertama apakah ada hubungan antara kontrol diri dan komitmen kerja dengan perilaku cyber-loafing. Hipotesis kedua apakah ada hubungan negatif antara kontrol diri dengan perilaku cyber-loafing dan hipotesis ketiga apakah ada hubungan negatif antara komitmen kerja dengan perilaku cyber-loafing. Hasil uji hipotesis pertama menunjukkan skor $\mathrm{R}=0,214$ dengan nilai $F=12,792$ tingkat signifikan $p=0,000(p<0,05)$. Hal ini menunjukkan bahwa ada hubungan antara kontrol diri dan komitmen kerja dengan perilaku cyber-loafing. Seperti yang sudah dijelaskan (Ozler \& Polat, 2012) bahwa terdapat beberapa faktor lain yang dapat menyebabkan rendahnya perilaku cyber-loafing kecuali kontrol diri dan komitmen kerja diantarnya seperti faktor organisasi seperti pembatasan penggunaan internet, konsekuensi negatif yang didapatkan ketika menggunakan internet, dukungan manajerial, persepsi rekan kerja mengenai norma, sikap kerja karyawan (ketidakadilan dalam pekerjaan, komitmen kerja dan kepuasan kerja) dan karakteristik kerja. Penelitian lain menemukan bahwa terdapat beberapa hal yang dapat meningkatkan intense cyberloafing antara lain faktor sikap dan persepsi yang positif terhadap internet Liberman dalam (Ozler \& Polat, 2012), faktor kebiasaan, sifat seperti rasa malu, kesepian, isolasi diri dan harga diri (Ozler \& Polat, 2012).

Berdasarkan uji diskripsi variabel cyber-loafing diketahui bahwa rata-rata tingkat cyberloafing pegawai negeri di dinas X Provinsi Jawa Tengah termasuk dalam kategori rendah. Hal tersebut diketahui berdasarkan skor mean empirik perilaku cyber-loafing sebesar 26,85 dengan presentase $20,62 \%$ yang menunjukkan bahwa sebanyak 97 responden memiliki perilaku cyber-loafing yang rendah.

Hasil uji hipotesis kedua hasil skor yang diperoleh $r_{x 1 y}=-0,461$ dengan nilai signifikansi 0,000 $(P<0,05)$. Hal ini menunjukkan bahwa ada hubungan negatif antara kontrol diri dengan perilaku cyber-loafing. Hasil yang telah diperoleh menunjukkan bahwa hipotesis kedua diterima. Semakin tinggi kontrol diri pegawai maka semakin rendah perilaku cyber-loafing yang dilakukan dan sebaliknya. Semakin rendah kontrol diri pegawai maka semakin tinggi perilaku cyber-loafing yang dilakukan pada saat jam kerja berlangsung.

Penelitian ini sejalan dengan penelitian yang telah dilakukan oleh (Ardilasari N. , 2016) yaitu ada hubungan negatif antara self-control dengan perilaku cyber-loafing pada pegawai negeri sipil artinya semakin tinggi kontrol diri seseorang maka semakin rendah perilaku cyber-loafing yang dilakukannya pada saat jam kerja. 
Penelitian ini selaras dengan penelitian yang dilakukan oleh (Sari \& Ratnaningsih, 2018) yang berjudul hubungan antara kontrol diri dengan intens perilaku cyber-loafing pada pegawai dinas $\mathrm{x}$ Provinsi Jawa Tengah. hasil yang diperoleh yaitu ada hubungan negatif yang signifikan antara kontrol diri dengan perilaku cyber-loafing.

Berdasarkan uji diskripsi variabel kontrol diri diketahui bahwa rata-rata tingkat kontrol diri pegawai negeri di dinas $X$ Provinsi Jawa Tengah termasuk dalam kategori sangat tinggi. Hal tersebut diketahui berdasarkan skor mean empirik kontrol diri sebesar 62,69 dengan presentase $71,13 \%$ yang menunjukkan bahwa sebanyak 97 responden memiliki tingkat kontrol diri yang sangat tinggi. Sejalan dengan pendapat dari (Ghufron \& Risnawati, 2010) bahwa semakin dewasa usia seseorang, mempengaruhi individu untuk memiliki kontrol diri yang tinggi. Individu yang memiliki kontrol diri yang tinggi dapat mempengaruhi seseorang untuk memunculkan intensi perilaku menyimpang yang rendah seperti perilaku cyber-loafing. Hal tersebut mendukung dari hasil penelitian ini yang mengungkapkan bahwa adanya hubungan negatif antara kontrol diri dan perilaku cyber-loafing pada pegawai negeri Dinas $X$ yang menunjukkan bahwa semakin tinggi kontrol diri maka akan semakin rendah perilaku cyber-loafing.

Hasil uji hipoteisis ketiga hasil skor yang diperoleh $r_{x 1 y}=-0,327$ dengan signifikasi 0,001 $(p<0,05)$. Hal ini menunjukkan bahwa ada hubungan negatif antara komitmen kerja dengan perilaku cyber-loafing. Hasil yang telah diperoleh menunjukkan bahwa hipotesis ketiga diterima. Semakin tinggi komitmen kerja pegawai terhadap sebuah instansi maka semakin rendah perilaku cyber-loafing yang dilakukan.

Berdasarkan uji diskripsi variabel komitmen kerja diketahui bahwa rata-rata tingkat komitmen kerja pegawai negeri di dinas $X$ Provinsi Jawa Tengah termasuk dalam kategori tinggi. Hal tersebut diketahui berdasarkan skor mean empirik kontrol diri sebesar 63,77 dengan presentase $47,42 \%$ yang menunjukkan bahwa sebanyak 97 responden memiliki tingkat komitmen kerja yang tinggi. Hal ini sesuai dengan pendapat dari Meyer dan Allen dalam (Fajrianthi, 2012) dimana pegawai yang memiliki komitmen kerja yang tinggi akan bertahan dalam instansi tersebut karena adanya rasa keinginan, rasa nyaman, rasa ingin menyelesaikan suatu pekerjaan dengan baik, dan rasa membutuhkan pekerjaan tersebut untuk keperluan kehidupan. Pegawai yang memiliki komitmen terhadap instansi atau oraganisasnya akan bekerja secara rutin dan fullday, tidak melakukan perilaku yang menyimpang dan mempercayai tujuan organisasi yang diraih.

\section{Kesimpulan}

Berdasarkan data yang sudah di dapatkan oleh peneliti, data disimpulkan antara lain :

1. Hipotesis pertama dalam penelitian ini diterima yaitu ada hubungan kontrol diri dan komitmen kerja dengan perilaku cyber-loafing terhadap pegawai negeri sipil di Dinas $\mathrm{X}$ Provinsi Jawa Tengah. Artinya kontrol diri dan komitmen kerja dapat digunakan untuk memprediksi perilaku cyber-loafing.

2. Hipotesis kedua dalam penelitian ini diterima yaitu ada hubungan yang negatif antara kontrol diri dengan perilaku cyber-loafing terhadap pegawai negeri di Dinas X Provinsi Jawa Tengah. Sehingga semakin tinggi kontrol diri maka semakin rendah perilaku cyber-loafing yang dilakukan oleh pegawai, dan juga sebaliknya semakin rendah kontrol diri maka semakin tinggi perilaku cyber-loafing yang dilakukan oleh pegawai di dinas tersebut. 
3. Hipotesis ketiga dalam penelitian ini diterima yaitu ada hubungan yang negatif antara komitmen kerja dengan perilaku cyber-loafing terhadap pegawai negeri di Dinas X Provinsi Jawa Tengah. Sehingga semakin tinggi komitmen kerja maka semakin rendah perilaku cyber-loafing yang dilakukan oleh pegawai, dan juga sebaliknya semakin rendah komitmen kerja maka semakin tinggi perilaku cyber-loafing yang dilakukan oleh pegawai di dinas tersebut.

\section{Daftar Pustaka}

APJII, A. P. (2017). Penetrasi dan perilaku pengguna internet indonesia. Jakarta: Teknopreneur.

Azwar, S. (2012). Penyusunan skala psikologi. Yogyakarta: Pustaka belajar.

Baumeister, R. F. (2002). Handbook of social psychology. New York: McGraw-Hill.

Baumeister, R. F., Vohs, K. D., \& Tice, D. M. (2007). The strength model of self disclosure. Journal of Psychological Science, 16 (6).

Blanchard, A. L., \& Henle, C. A. (2008). The Interaction of Work Stressors and Organizational Sanctions on Cyber-loafing. Journal of Managerial Issues, 383-400.

Blanchard, A., \& Henle, C. (2008). Correlates of different forms of cyber-loafing: The role of norms and external locus of control. Computers in Human Behavior, 24, 1067-1084.

Fajrianthi. (2012). Hubungan antara komitmen organisasi dengan kesiapan untuk berubah pada karyawan divisi enterprise service (DES) telkom ketintang surabaya. Jurnal Psikologi Industri dan Organisasi, 102-109.

Ghufron, M. N., \& Risnawati, R. (2010). Teori-teori psikologi. Yogyakarta: Ar-Ruzz Media.

Henle, C. A., \& Kendharnath, U. (2012). Cyber-loafing the workplace. Encyclopedia of Research on Cyber Behaviour, 1, 560-573.

Lim, V. K., \& Chen, D. J. (2012). Cyber-loafing at the workplace: Gain or drain on work? Behaviour and Information Technology, 23, 675-694.

Mathis, R. L., \& Jackson, J. H. (2008). Manajemen Sumber Daya Manusia. In Terjemahan Dian Angelia. Jakarta: Salemba empat.

Ozler, D. E., \& Polat, G. (2012). Cyber-loafing phenomenon in organizations: Determinants and impacts. International Journal of Ebusiness and Egovernment Studies, 4(2). 